\title{
Lingkar pinggang: Penentu arus puncak ekspirasi
}

\author{
Kristiana Prasetya Handayani ${ }^{{ }^{*}}$,Bernadette Cristie Binardia Ayu Puspitawati ${ }^{2}$, Maria Elisabeth Wati \\ Windayani $^{3}$ \\ 1,2,3 Stikes ST Elisabeth Semarang, Indonesia \\ *Coresponding Author: devanosetiawan@gmail.com
}

\begin{abstract}
Abstrak
Pendahuluan: Lingkar pinggang berlebih dialami 28,9\% penduduk Indonesia, dimana berpotensi menyebabkan penurunan arus puncak ekspirasi (APE). Tujuan penelitian yaitu untuk mengetahui korelasi antara lingkar pinggang dengan arus puncak ekspirasi. Metode: Penelitian ini berjenis analisis kuantitatif korelasional dengan pendekatan cross sectional pada Juni 2019, dengan sampel sejumlah 32 orang mahasiswi keperawatan di Semarang, dan dipilih dengan tehnik simple random sampling. Analisa data menggunakan uji pearson dengan $\alpha$ 0,05 . Hasil: terdapat korelasi antara lingkar pinggang dengan arus puncak ekspirasi pada mahasiswi. Simpulan: semakin tinggi lingkar pinggang, maka semakin rendah nilai arus puncak ekspirasi.
\end{abstract}

Kata kunci: Lingkar pinggang; arus puncak ekspirasi; mahasiswi

\section{Waist circumference: Determinant of peak expiratory flow}

\begin{abstract}
Introduction: Incidence of excess waist circumference is $26,6 \%$ of Indonesian, which has the potential to cause a decrease in peak expiratory flow. The purpose of this study is to determine the correlation between waist circumference with peak expiratory current. Methods: This study is a quantitative correlational analysis with a cross sectional approach, with a sample of 32 nursing students in Semarang, and selected by simple random sampling technique. Data analysis using Pearson test with $\alpha 0.05$. Results: There is a correlation between waist circumference with peak expiratory flow in female college students. Conclusions: The higher waist circumference, make the lower the peak expiratory flow value.
\end{abstract}

Keywords: Peak expiratory flow; waist circumference; college student

How to Cite: Handayani, K.,P., Puspitawati, B.,C.,B.,A., \& Windayani, M.,E.,W. (2020). Lingkar pinggang: Penentu arus puncak ekspirasi. NURSCOPE: Jurnal Penelitian dan Pemikiran IImiah Keperawatan, 6(1).15-21

\section{PENDAHULUAN}

Prevalensi obesitas di Indonesia meningkat. Laporan Riset Kesehatan Dasar (Riskesdas) 2013 menyebutkan presentase gizi dewasa berusia di atas 18 tahun menurut indeks masa tubuh yaitu berat badan berlebih (13,5\%), dan obesitas (15,4\%). Prevalensi obesitas di kota Semarang pada tahun 2013 sebesar 28,4 \% pada wanita dan 7,2 \% pada laki-laki (Badan Penelitian dan Pengembangan Kesehatan, 2013). Obesitas meningkatkan resiko seseorang mengalami penyakit jantung, dan mengalami kematian akibat henti jantung (Darmawan, Sujianto, \& Rochana, 2018). Salah satu cara untuk menentukan obesitas sentral seseorang yaitu dengan pengukuran lingkar pinggang (waist circumference). Menurut WHO, lingkar pinggang bagi wanita Asia adalah $\geq 80 \mathrm{~cm}$ dan bagi laki - laki Asia $\geq 90 \mathrm{~cm}$. Seseorang yang memiliki lingkar pinggang berlebih umumnya menyimpan lemak di bawah kulit dinding abdomen dan di rongga abdomen. Bagian perut yang gemuk membuat bentuk tubuh pasien seperti buah apel (Hartono \& Andri, 2016). Lingkar pinggang mempengaruhi nilai puncak arus respirasi seseorang (Sholeh, 2015). Hasil penelitian Sholeh (2015) tentang hubungan lingkar pinggang dengan arus puncak ekspirasi (APE) pada populasi sindrom metabolik, didapatkan hasil bahwa semakin tinggi lingkar pinggang, maka semakin rendah arus puncak ekspirasi. 
Hasil studi pendahuluan yang dilakukan di Semarang didapatkan 34 mahasiswi mengalami obesitas dan memiliki lingkar pinggang $>80 \mathrm{~cm}$. Mereka mengatakan bahwa lebih mudah lelah dan napas terengah-engah jika melakukan sedikit aktivitas berat. Peneliti juga menemukan fenomena bahwa sebagian besar mahasiswi yang tidak menjaga pola makan dan hidup sehat dengan berolahraga sementara usia mereka masih termasuk dalam kategori dewasa muda dimana fungsi pernapasan mereka belum mengalami banyak penurunan. Peneliti tertarik untuk melakukan penelitian berjudul Korelasi antara Lingkar Pinggang dengan Arus Puncak Ekspirasi pada Mahasiswi Obesitas di Semarang agar sedini mungkin penyakit pernapasan dan efek buruk lain dari obesitas pada mahasiswi dapat dicegah dan diminimalkan. Tujuan penelitian ini untuk mengetahui korelasi antara lingkar pinggang dengan arus puncak ekspirasi pada mahasiswi obesitas di Semarang.

\section{METODE}

Desain penelitian ini menggunakan desain observasional analitik dengan pendekatan waktu secara cross sectional (belah lintang). Populasi pada penelitian ini adalah mahasiswi keperawatan di Semarang. Teknik pengambilan sampel yang digunakan yaitu menggunakan simple random sampling. Sampel dalam penelitian ini sejumlah 32 orang. Adapun kriteria inklusi yaitu berjenis kelamin perempuan, berusia $18-24$ tahun, memiliki lingkar pinggang $>80 \mathrm{~cm}$, memiliki IMT $\geq 25 \mathrm{~kg} / \mathrm{m}^{2}$. Penelitian ini dilakukan di Semarang pada tanggal 7 Juni 2018 (Dharma, 2013).

\section{HASIL DAN PEMBAHASAN}

Rerata usia responden adalah $20.38 \pm 1.24$ tahun dengan usia minimal 18 tahun dan usia maksimal 24 tahun dimana responden yang paling banyak adalah responden yang berusia 20 tahun sebanyak 10 orang dengan persentase $31,3 \%$ (Tabel 1 ). Berikut merupakan hasil karakteristik responden menurut usia.

Tabel 1. Rerata Usia Responden

\begin{tabular}{lcc}
\hline Variabel & Mean \pm SD & Median (Min - Max) \\
\hline Usia & $20.38 \pm 1.24$ & $20(18-24)$ \\
\hline
\end{tabular}

Rerata tinggi badan responden berdasarkan Tabel 2 adalah $157.16 \pm 4.33 \mathrm{~cm}$ dengan tinggi badan minimal $147 \mathrm{~cm}$ dan tinggi badan maksimal $170 \mathrm{~cm}$ dimana responden yang paling banyak adalah responden yang memiliki tinggi badan $155 \mathrm{~cm}$ dan $158 \mathrm{~cm}$ sebanyak masing-masing 7 orang dengan persentase $21,9 \%$. Berikut merupakan hasil karakteristik responden berdasarkan tinggi badan

Tabel 2. Rerata Tinggi Badan Responden

\begin{tabular}{lcc}
\hline Variabel & Mean \pm SD & Median (Min - Max) \\
\hline Tinggi & $157.16 \pm$ & $157.50(147-170)$ \\
Badan & 4.33 & \\
\hline
\end{tabular}

Rerata Indeks Massa Tubuh responden adalah $29.08 \pm 2.45 \mathrm{~kg} / \mathrm{m}^{2}$ dengan IMT minimal $25 \mathrm{~kg} / \mathrm{m}^{2}$ dan IMT maksimal $33.74 \mathrm{~kg} / \mathrm{m}^{2}$ dimana responden yang paling banyak termasuk dalam klasifikasi obese 1 dengan IMT 25.0 - 29.9 sebanyak 18 orang dengan persentase 56,3\% (Tabel 3 dan 4). Berikut merupakan hasil karakteristik responden berdasarkan indeks massa tubuh.

Tabel 3. Karakteristik IMT Responden

\begin{tabular}{lcc}
\hline \multicolumn{1}{c}{ IMT } & Frekuensi & Presentase (\%) \\
\hline Obese 1 & 18 & 56,3 \\
Obese 2 & 14 & 43,7 \\
Total & 32 & 100 \\
\hline
\end{tabular}


Tabel 4. Rerata IMT Responden

\begin{tabular}{lcc}
\hline Variabel & Mean \pm SD & Median (Min - Max) \\
\hline IMT & $29.08 \pm 2.45$ & $\begin{array}{c}28.67 \\
(25-33.74)\end{array}$ \\
\hline
\end{tabular}

Rerata Lingkar Pinggang responden adalah $87.63 \pm 4.77 \mathrm{~cm}$ dengan Lingkar Pinggang minimal $81 \mathrm{~cm}$ dan Lingkar Pinggang maksimal $97.5 \mathrm{~cm}$ dimana responden paling banyak memiliki Lingkar Pinggang sebesar $81-90 \mathrm{~cm}$ sebanyak 23 orang dengan persentase 72\% (Tabel 5). Berikut merupakan hasil karakteristik responden berdasarkan lingkar pinggang.

Tabel 5. Rerata Lingkar Pinggang Responden

\begin{tabular}{lcc}
\hline Variabel & Mean \pm SD & Median (Min - Max) \\
\hline Lingkar & 87.63 & 87.50 \\
Pinggang & \pm 4.77 & $(81-97.50)$ \\
\hline
\end{tabular}

Rerata Arus Puncak Ekspirasi responden adalah $325.31 \pm 53.88 \mathrm{~L} / \mathrm{mnt}$ dengan APE minimal $220 \mathrm{~L} / \mathrm{mnt}$ dan APE maksimal $420 \mathrm{~L} / \mathrm{mnt}$. Berikut merupakan hasil karakteristik responden berdasarkan APE (Tabel 6).

Tabel 6. Rerata APE Responden

\begin{tabular}{lcc}
\hline Variabel & Mean \pm SD & Median (Min - Max) \\
\hline \multirow{2}{*}{ APE } & $325.31 \pm$ & 325 \\
& 53.88 & $(220-420)$ \\
\hline
\end{tabular}

Hasil uji pearson didapatkan $p$ value yaitu 0,022 dimana $p$ value tersebut $<0,05$ yang berarti bahwa $\mathrm{HO}$ ditolak dan $\mathrm{H} 1$ diterima. Selain itu, didapatkan pula nilai koefisien korelasi $(r)$ yaitu $-0,403$ yang berarti korelasi antara lingkar pinggang dengan arus puncak ekspirasi bersifat sedang dan negatif dimana ketika lingkar pinggang mengalami peningkatan, maka arus puncak ekspirasi mengalami penurunan. Sehingga dapat disimpulkan ada korelasi antara lingkar pinggang dengan arus puncak ekspirasi pada mahasiswi obesitas di Semarang dengan kekuatan korelasi negatif sedang (Tabel 7). Berikut merupakan hasil korelasi lingkar pinggang dengan APE

Tabel 7. Korelasi lingkar pinggang dengan APE

\begin{tabular}{|c|c|c|}
\hline \multirow{2}{*}{ Variabel } & \multicolumn{2}{|c|}{ Arus Puncak Ekspirasi } \\
\hline & $r$ & $p$ \\
\hline $\begin{array}{l}\text { Lingkar } \\
\text { Pinggang }\end{array}$ & $-0,403$ & 0,022 \\
\hline
\end{tabular}

Usia responden yang paling banyak adalah responden yang berusia 20 tahun yaitu sebanyak 10 orang. Sebanyak22 dari 32 responden mengatakan bahwa memiliki kebiasaan snacking dan 13 dari 32 responden memiliki pola tidur yang kurang. Hal ini sesuai dengan penelitian Pratiwi dan Nidya tahun 2017 bahwa snacking dapat mengakibatkan peningkatan pada lemak jenuh bila tidak diimbangi dengan pengurangan makanan utama. Selain itu, waktu tidur yang kurang ( $<6$ jam) dapat mempengaruhi kerja leptin dan ghrelin yang memicu munculnya rasa lapar sehingga seseorang menjadi overeating (Pratiwi \& Nindya, 2017).

Responden sebanyak 22 dari 32 juga mengatakan jarang berolahraga dan 21 dari 32 responden jarang melakukan aktivitas berat. Mereka lebih banyak menghabiskan waktunya dengan duduk atau sedikit gerakan badan, menggunakan kendaraan bermotor sehingga tidak perlu berjalan kaki jarak jauh, dan pekerjaan lain yang tidak membutuhkan banyak usaha fisik. Hal ini sejalan dengan penelitian (Diana, Yuliana, Yasmin, \& Hardiansyah, 2013) bahwa seseorang yang beraktivitas fisik ringan berisiko lebih 
tinggi untuk mengalami kegemukan. Usia dapat mempengaruhi arus puncak ekspirasi. Berdasarkan teori, semakin bertambahnya usia seseorang, fungsi paru akan mengalami penurunan. Elastisitas dinding torak dan alveoli yang menurun mengakibatkan penurunan kapasitas paru dan difusi oksigen (Guyton \& Hall, 2014).

Rentang usia dalam penelitian ini merupakan kategori dewasa muda yang belum memiliki masalah dengan penurunan fungsi organ, sehingga penurunan arus puncak ekspirasi yang dialami responden juga dapat disebabkan oleh pola hidup yang kurang baik. Terdapat 22 dari 32 responden tidak menjaga pola makan dan hidup sehat dengan berolahraga (Diana et al., 2013). Hasil penelitian didapatkan bahwa APE tertinggi yaitu $420 \mathrm{~L} / \mathrm{mnt}$ terdapat pada responden dengan usia 20 dan 21 tahun. Hal ini sesuai dengan penelitian Yunus di tahun 2013 bahwa faal paru meningkat volumenya dan mencapai maksimal pada usia 19 - 21 tahun. Sedangkan, APE terendah yaitu 220 L/mnt terdapat pada responden dengan usia 21 tahun. Hal ini dapat diakibatkan karena faktor psikologisdan aktivitas fisik. Responden tersebut mengatakan sering mengalami cemas dan stress akibat tugas maupun masalah pribadi (RI, 2013).

Stress dan cemas dapat merangsang hormon katekolamin di hipotalamus untuk memproduksi efinefrin dan norefinefrin. Hormon tersebut dapat meningkatkan denyut jantung dan pernafasan sehingga seseorang cenderung bernafas dangkal dan cepat. Stress dan cemas dapat menurunkan kemampuan beraktifitas seseorang (Rendi Editya Darmawan \& Sudiro, 2020). Inspirasi dan ekspirasi yang tidak maksimal menyebabkan menurunnya kapasitas residu fungsional yang berakhir pada penurunan arus puncak ekspirasi (Abidin, Yunus, WH, \& A., 2013). Selain itu, responden tersebut juga mengatakan tidak pernah berolahraga dan jarang melakukan aktivitas berat. Hal ini dapat mengakibatkan otot interkosta dan diafragma tidak terlatih dan daya regang paru menurun. Kerja dan fungsi pernafasan menjadi tidak efektif sehingga berpengaruh juga pada Arus Puncak Ekspirasi (Agustin \& Yunus, 2015).

Tinggi badan memiliki pengaruh pada obesitas karena tinggi badan adalah salah satu parameter yang digunakan untuk menghitung Indeks Massa Tubuh sehingga seseorang dapat dikatakan obesitas. Tinggi badan juga mempengaruhi arus puncak ekspirasi. Fungsi ventilasi paru berhubungan dengan tinggi badan, sehingga nilai APE lebih besar pada orang yang memiliki tinggi badan lebih. Tinggi badan sangat mempengaruhi anatomi paru khususnya luas permukaan paru. Semakin tinggi seseorang, semakin luas parunya sehingga kapasitas paru lebih baik (Abidin et al., 2013).

Pada hasil penelitian didapatkan bahwa APE terendah yaitu $220 \mathrm{~L} / \mathrm{mnt}$ terdapat pada responden dengan rentang tinggi $155-159 \mathrm{~cm}$ dan tidak pada rentang tinggi yang lebih kecil. Sedangkan, APE tertinggi yaitu $420 \mathrm{~L} / \mathrm{mnt}$ terdapat pada responden dengan rentang tinggi $155-159 \mathrm{~cm}$ dan tidak pada rentang tinggi yang lebih besar (Pratiwi \& Nindya, 2017). Hal ini dapat diakibatkan pada saat pengukuran APE, kekuatan daya elastisitas paru untuk menghasilkan ekspirasi yang diperlukan, berbeda setiap respondennya. Hal ini sesuai dengan Penelitian Khaliza Cita pada tahun 2014 bahwa terdapat korelasi positif antara kekuatan otot dada dengan arus puncak ekspirasi. Semakin kuat otot dada, semakin besar pula volume rongga dada sehingga kapasitas udara masuk meningkat. Selain itu, tenaga yang diperlukan untuk mendorong udara ke atas melawan dasar diafragma juga akan mempengaruhi kekuatan hembusan nafas setiap responden (Kresnanda, 2014).

Indeks Massa Tubuh dapat digunakan untuk mengukur obesitas pada seseorang dengan cara membagi Berat Badan (BB) dalam kg dengan Tinggi Badan (TB) dalam meter dikuadratkan. Indeks Massa Tubuh mempengaruhi arus puncak ekspirasi. Pada orang yang memiliki berat badan lebih, terdapat akumulasi lemak pada bagian abdomen, dada, dan diafragma. Akumulasi lemak di area tersebut dapat mengubah daya regang paru, kerja pernapasan, dan keelastisan rongga torak. Lemak tersebut dapat menekan dan membatasi gerakan diafragma ketika bernafas, sehingga beban otot pernafasan 
meningkat dan terjadi pengurangan volume paru dan laju aliran udara terutama Arus Puncak Ekspirasi (APE) (WHO, 2014).

Pada penelitian ini, APE tertinggi yaitu $420 \mathrm{~L} / \mathrm{mnt}$ ada pada responden dengan kategori obesitas 1 (IMT $25-29,9 \mathrm{~kg} / \mathrm{m}^{2}$ ) dan obesitas 2 (IMT > 29,9 kg/m²). Sedangkan APE terendah yaitu $220 \mathrm{~L} / \mathrm{mnt}$ ada pada responden dengan kategori obesitas 1 (IMT 25-29,9 kg/m²). Hal ini dapat disebabkan oleh perbedaan aktivitas fisik yang dilakukan pada kegiatan sehari-hari tiap responden. Pada penelitian Angkit Kinasih dkk di tahun 2018 menyebutkan bahwa terdapat beberapa responden dengan IMT tinggi dan APE yang tinggi.

Aktivitas sehari-hari dapat mempengaruhi kapasitas vital paru seseorang. Hal ini sesuai dengan penelitian Haningtyas Endah Putriani dkk di tahun 2018 bahwa terdapat perbedaan peningkatan APE yang bermakna setelah melakukan latihan skipping jika dibandingkan dengan kelompok kontrol. Pada seseorang dengan aktivitas fisik yang rutin, otot interkosta dan diafragma akan lebih kuat sehingga daya regang paru meningkat. Peningkatan jumlah udara inspirasi dan ekspirasi akan membuat kerja dan fungsi pernafasan lebih efektif sehingga berpengaruh juga pada Arus Puncak Ekspirasi.

Korelasi lingkar pinggang dan arus puncak respirasi tergambar pada hasil berikut. Responden paling banyak memiliki lingkar pinggang antara $81-90 \mathrm{~cm}$ sebanyak 23 orang. Peningkatan berat badan sering diikuti dengan peningkatan penumpukan lemak dibagian abdominal tubuh. Pasien dengan obesitas akan mengalami perubahan ukuran lingkar pinggang akibat penumpukan lemak di daerah tersebut. Lingkar pinggang berlebih yang diakibatkan akumulasi lemak yang berlebihan di bagian abdomen menyebabkan terjadinya peningkatan dan penurunan Interleukin 6 (IL - 6), leptin, dan adiponektin sehingga mengakibatkan terjadinya remodeling jalan nafas dan berakhir pada penurunan arus puncak ekspirasi.

Selain itu, akumulasi lemak di area tersebut dapat mengubah daya regang paru, kerja pernapasan, dan keelastisan rongga thorak. Lemak tersebut dapat menekan dan membatasi gerakan diafragma ketika bernapas, sehingga menyebabkan compliance paru rendah. Beban otot pernapasan menjadi meningkat, alveoli kolaps dan mengakibatkan terjadinya gangguan pernapasan mekanik, resistensi aliran udara, pola pernapasan dan pertukaran gas. Hal itu mengakibatkanterjadinya penurunan kapasitas residu fungsional dan berakhir pada penurunan arus puncak ekspirasi.

Pada penelitian ini, lingkar pinggang yang semakin meningkat akan menurunkan arus puncak ekspirasi responden. Dibuktikan dengan hasil uji pearson, dimana didapatkan $p$ value 0,022 dan $r-0,403$. Hal ini sejalan dengan penelitian Ihwanu Sholeh di tahun 2015 bahwa terdapat korelasi negatif bermakna derajat sedang lingkar pinggang dengan arus puncak ekspirasi pada populasi sindrom metabolik.

Penelitian ini juga menunjukkan bahwa APE tertinggi yaitu $420 \mathrm{~L} / \mathrm{mnt}$ ada pada responden dengan lingkar pinggang $82 \mathrm{~cm}$ dan $82,5 \mathrm{~cm}$. Hal ini sesuai dengan arah korelasi pada uji pearsonyaitu negatif $(r=-0,403)$ yang menjelaskan bahwa semakin kecil lingkar pinggang, maka semakin tinggi nilai APE, begitupun sebaliknya. Sedangkan APE terendah yaitu $220 \mathrm{~L} / \mathrm{mnt}$ ada pada responden dengan lingkar pinggang $81,5 \mathrm{~cm}$, bukan pada responden dengan lingkar pinggang diatas $90 \mathrm{~cm}$.

Hal ini dapat diakibatkan oleh beberapa faktor yaitu psikis, aktivitas, dan polusi udara. Responden tersebut mengatakan sering merasa cemas dan stress karena tugas perkuliahan dan masalah pribadinya. Cemas dan stress dapat mengakibatkan seseorang bernafas dangkal dan cepat yang akan menurunkan arus puncak ekspirasi. Selain itu, responden tersebut mengatakan jarang melakukan aktivitas berat dan berolahraga. Ketika otot interkosta dan diafragma tidak dilatih, kerja dan fungsi pernafasan menjadi tidak efektif sehingga berpengaruh pada arus puncak ekspirasinya. 
Responden juga mengatakan menggunakan obat nyamuk bakar dan sering terpapar asap rokok di rumahnya. Hal ini sesuai dengan penelitian Andrian Rivanda di tahun 2015 bahwa terdapat pengaruh paparan karbon monoksida terhadap perubahan pada sistem pernafasan. Polusi udara banyak macamnya, antara lain : asap obat nyamuk bakar, asap rokok, gas buang dari kendaraan bermotor, dan debu. Polusi udara mengandung zat-zat yang dapat menimbulkan peradangan pada paru. Hal itu menyebabkan hiperplasia kelenjar mukus, penebalan mukosa, spasme pada otot saluran pernafasan yang mengganggu fungsi paru sehingga nilai APE rendah walaupun ukuran lingkar pinggang kecil (PDPI, 2013).

\section{SIMPULAN DAN SARAN}

Dari hasil penelitian tentang korelasi antara lingkar pinggang dengan arus puncak ekspirasi pada mahasiswi obesitas di Semarang, maka dapat disimpulkan sebagai berikut : karakteristik responden dengan rerata usia responden 20,38 tahun sebanyak 10 responden (31,3\%), dengan rerata tinggi badan 157,50 sebanyak 7 responden (21,9\%), dan rerata Indeks Massa Tubuh responden adalah 29,08 sebanyak 18 responden $(56,3 \%)$ dan sebagian besar termasuk dalam kategori Obese. Rerata lingkar pinggang pada penelitian ini adalah $87.63 \pm 4.77 \mathrm{~cm}$ dan sebagian besar responden memiliki lingkar pinggang sebesar $81-90 \mathrm{~cm}$. Rerata arus puncak ekspirasi pada penelitian ini adalah $325.31 \pm$ $53.88 \mathrm{~L} / \mathrm{mnt}$ dan sebagian besar APE pada mahasiswi termasuk dalam kategori tidak normal. Hasil dari uji statistik pada lingkar pinggang dan arus puncak ekspirasi menunjukkan hasil $p$ value $0,022(p<0,05)$ yang berarti ada korelasi antara lingkar pinggang dengan arus puncak ekspirasi pada mahasiswi obesitas di Semarang dengan arah korelasi negatif lemah $(r=-0,403)$ yang berarti semakin tinggi lingkar pinggang semakin rendah nilai APE.

Peneliti selanjutnya dapat menambah jumlah responden dan melakukan pengukuran lingkar pinggang dan arus puncak ekspirasi pada orang yang memiliki lingkar pinggang normal dan berlebih sehingga dapat membandingkan perbedaan arus puncak ekspirasi antara keduanya.

\section{DAFTAR PUSTAKA}

Abidin, Yunus, WH, W., \& A., R. (2013). Manfaat Rehabilitasi Paru dalam Meningkatkan atau Mempertahankan Kapasiti Paru Fungsional pada Pasien Penyakit Paru Obstruktif Kronik di RSUP Persahabatan. Jurnal Respiratologi Indonesia, 29(2).

Agustin, H., \& Yunus, F. (2015). Proses Metabolisme pada PPOK. J Respir Indo, 28(3), 12-19.

Badan Penelitian dan Pengembangan Kesehatan. (2013). Laporan Hasil Riset Kesehatan Dasar Indonesia tahun 2013. Jakarta: Kementerian Kesehatan RI.

Darmawan, R.E., Sujianto, U., \& ROchana, N. (2018). Effects of neo automatic code on the accuracy of chest compression depths in cardiac arrest patients. Hiroshima Journal of Medical Sciences, 67.

Darmawan, Rendi Editya, \& Sudiro, S. (2020). Upaya dan Kendala Konselor Puskesmas dalam Perawatan Pasien Skizofrenia. Interest:Jurnal IImu Kesehatan, 9(1), 81-86. https://doi.org/https://doi.org/10.37341/interest.v9i1.194

Dharma, K. K. (2013). Metodologi penelitian keperawatan (12th ed.). Jakarta: Trans Info Media.

Diana, Yuliana, Yasmin, \& Hardiansyah. (2013). Faktor Risiko Kegemukan Pada Wanita Dewasa Indonesia. Jurnal Gizi Dan Pangan, 8(1), 1-8.

Guyton \& Hall. (2014). Buku Ajar Fisiologi Kedokteran Edisi 12. Jakarta: EGC. 
Hartono \& Andri. (2016). Terapi Gizi dan Diet Rumah Sakit, Ed. 2. Jakarta: EGC.

Kresnanda. (2014). Hubungan Kekuatan Otot Dada dengan Arus Puncak Ekspirasi pada Peserta Senam Asma Usia Dewasa di Balai Kesehatan Paru Masyarakat Kota Semarang. Jurnal Media Medika Muda, 4(1), 11-14.

PDPI. (2013). Penyakit Paru Obstruksi Kronik. In Pedoman Diagnosis dan Penatalaksanaan PPOK di Indonesia (p. 1).

Pratiwi, \& Nindya. (2017). Hubungan Konsumsi Camilan dan Durasi Waktu Tidur dengan Obesitas di Pemukiman Padat Kelurahan Simolawang. Amerta Nutrition. Jurnal Nutrisi, 1(13), 153-161.

RI, K. (2013). Status Gizi Dewasa. Jakarta: Kementerian Kesehatan RI.

Sholeh, I. (2015). Hubungan Lingkar Pinggang dengan Arus Puncak Ekspirasi pada Populasi Sindrom Metabolik. Media Medika Muda, 4(4), 3-9.

WHO. (2014). 10 Facts on Obesity. Retrieved from WHO website: http://www.who.int/features/factfiles/obesity/en/ 